\title{
Investigation Of Acute Toxicological Effects Of Diesels Fuel In Rats (Rattus rattus) Using Histopathological Methods
}

\author{
*DEDE E. B; KAGBO, H. D \\ Department of Pharmacology and Toxicology, College of Health Sciences,University of Port Harcourt, P. M. B. 5323, Port Harcourt, \\ Nigeria
}

\begin{abstract}
Acute toxicological effects of diesel fuel in rats were investigated. The $\mathrm{LD}_{50}$ value was determined as $70.6 \mathrm{glkg}$ using rats of $0.2 \mathrm{~kg}$ body weight. Histopathological examination of rat tissues after exposure of rat groups to $0.9 \%$ saline (controlgroup), $\mathrm{LD}_{50}$ and $\mathrm{LD}_{100}$ of diesel fuel for 24 hour revealed black deposits and inplamination respectively in the pulmonary interstitium, and necrosis of the kidney and liver of rats administered with diesel fuel. From the international classification of the toxicity of chemicals based on their $\mathrm{LD}_{50}$ values, diesel fuel seemed to be relatively harmless, however, there is the need for caution in the use of the petroleum product as direct effect of it on tissues indicated toxicity. @ JASEM
\end{abstract}

Diesel fuel is a mixture of hydrocarbons. It has a chemical composition of $12-20$ carbon atoms per mrlecule, and approximately 30\% n-paraffin, 45\% cyclocalkanes and 25\% aromatics (Frankenberger and Johanson, 1982, speight, 1992).

The toxicological effect of any substance may be explained as an interference with the cellular or subcellilar process, which leads to a disruption of the normal metabolism of a living organism upon exposure to such substance.

Petroleum hydrocarbon magnified their toxic effects by competing with some endogenous metabolites or block some pathways, this interference may or may not be lethal (kiihuhold, 1980),

The toxic effects of petroleum hydrocarbon are exerted on variety of organs of living systems such as the lungs, liver and kidney (Ervom, 1983; Akubue, 1997). Most of the available information on the toxic effects of diesel fuel has been with the type refined and used in developed countries of the world. And, it is known that the constrtiment of petroleum products reflects the properties of the crude oil from which they are distillerd (IPCS, 1982). It is against this backdrop that it is important to inventrgate the toxicological effects of diesel fuel refrined and used in developing countries. This study examines the acute toxicological effects of diesel fuel in commercial use in Nigeria with a viaw to assessing the degree of organ damage at two lethal dozen.

\section{MATERIALS AND METHOD}

Diesel fuel used as toxicant in this study was obtained from a commercial filling station (Matelbot oil) in Port Harcourt .Rat used for the study were obtained from Rivers State University of science and Technology animal house, and Quality control and Testrys (Q C \& T) Labroatines, all in Port Harcourt, Nigeria. The rats were pooled and fed together in the environment in which the test was carried out for 14 days before the test.

*Corresponding author
For the purpose of determining the median lethal doze $\left(\mathrm{LD}_{50}\right)$, five groups of rats were administered with different dozes $(65 \mathrm{gkg}, 87 \mathrm{~kg}, 109 \mathrm{~g} \mathrm{Ikg}$ and 131gIkg) of diesel fuel and observed for 24hours. Animals were rerouted dead when they no longer responded to prodding and agitation. The number of dead animals were recorded. The median lethal doze $\left(\mathrm{LD}_{50}\right)$, it $70.6 \mathrm{G} \mathrm{Ikg}$ and the lowest doze that killed all the animals in a group $\left(\mathrm{LD}_{100}\right)$, ie $109 \mathrm{~g} \mathrm{Ikg}$, were then administered to a fresh group of rats, $0.9 \%$ saline was aboadministered to a group of rats which served as the control group. A representative dead animal who taken from the rats administered with diesel fuel and dissected to obtain the lungs, liver and kidney. An animal was also killed from the control group and dissected to obtain the above organs. These organs were preserved in $10 \%$ formaldehyde.

The preserved organs were sliced and dehydrated in ethylalcohol with a concentration range of $50-100 \%$ and cleared with xylare. The sliced tissues were embedded in molten paraffin was to form "tissue blocks" which were sectioned with with a shandon. AS 3225 rotary macrodome. Shides made with the sectioned tissues were stained with haematoxyhin /eosin and photographed with the Leitz camera microscope (Dialux 20 moded).

\section{RESULTS AND DISCUSSION}

The histopathohgical study of the lung of rats administered with diesel fuel showed induced lesions. There were deposits of black materials in the lung interstrtum of those administered with the medium lethal doze $\left(L D_{50}\right)$. This feature has been reported as a manifestation of aspiration lipoid preanumd following petroleum product providing (Becklake, 1979). Furthermore, those administered with the linger doze $\left(\mathrm{LD}_{100}\right)$ showed diffuse interstitial pulrionay fibrosis this caused diminished acration of the lungs (atelectasis ), with conoeqnuent pulmonary hypoxia. 
Table 1.

\begin{tabular}{|l|l|l|l|}
\hline Tissue & \multicolumn{1}{|c|}{$\mathrm{ld}_{50}$} & \multicolumn{1}{|c|}{$\operatorname{ld}_{100}$} & Toxicological effect. \\
\hline Lung & $\begin{array}{l}\text { Deposit of black } \\
\text { materials in the } \\
\text { pulmonary inteshtium } \\
\text { (plate1) }\end{array}$ & $\begin{array}{l}\text { Heary infiltration of } \\
\text { alveolar sepatae by } \\
\text { inflammatory cell } \\
\text { (plate 2) }\end{array}$ & $\begin{array}{l}\text { The black deposits are consistent with the } \\
\text { chemical histopathology of aspiration } \\
\text { lipoid prieumonia (Becklake, 1979). } \\
\text { Infiltration of the septae is ause of } \\
\text { diffuse interstitial fibrosis and pulmonary } \\
\text { Hypoxia. }\end{array}$ \\
\hline Liver & $\begin{array}{l}\text { Narrowing of sinuses } \\
\text { (plate 3) }\end{array}$ & $\begin{array}{l}\text { Severe hepatocellelar } \\
\text { necrosis } \\
\text { (plate 4) }\end{array}$ & $\begin{array}{l}\text { Acute hepatic injury. This shows that } \\
\text { Diesel fuel is a hepatotoxin }\end{array}$ \\
\hline kidney & $\begin{array}{l}\text { Disfusely } \\
\text { tubular necnisin } \\
\text { (plate 5) }\end{array}$ & $\begin{array}{l}\text { Acute renal failure } \\
\text { (plate 6) }\end{array}$ \\
\hline
\end{tabular}

Death caused by petroleum product poisoning has been ascribed more to pulmonary hypoxia than to induced damage in other organ systems (Ervin, 1983). Examination of the liver showed a doze dependent hepatocellular neurosis in the rats. Jeffries (1979) defined hepaloxias as any agent that cause liver injury after a relatively short period, and which may cause liver cell necrosis alone or with actered enzyme activity and biting tract dysfemetion. From this study, diesel fuels. Texaco nephropathy refers to any adverse alteration in structure and function of renal tubular from exposure to exogenous chemical. It presents as tubular dysfunction, acute renal failure and, if exposure is prolonged, chronic renal failure. Tubular necrosis had been reported to be a common cause of acute renal failure (Anderson and Schria, 1991).

This study has therefore confirmed previous reports they diesel fuel and indeed other petroleum hydrocarbon are nephrotoxic and could cause acute real failure (Barrientos teal, 1977, Emmerson, 1979, Anderson Schrier, 1991.)

\section{REFERENCES}

Akiubue, P. (1997). Poisons in our Environment and Drug overdose: A Guide for Health Professionals And the lay public. Snaps Press LTD, Enugu, P 35.

Anderson R J.and Schrier, RW (1991), Acute renal failure. In: Harrison's Principle of Internal Medicine. Wilson JD, Braunwald E, Isselbacher KJ, Petersdorf FRG; Martin JB; Fanci As; Root RK (Des) $12^{\text {th }}$ Ed; McGraw Hill Inc. New York, 2:1144-1149.

Barreintos, A.; Oration, MT; Tellor, FM; Rodicio, J.L. (1977) acute renal failure after use of diesel fuel as shampoo. Arc. Intern. Med. 137:1217.
Becklake, M.R (1979). Interstitial (Lippoid) Pneumonia. In: Cecil Textbook of Medicine. Beeson, P.B; McDermott, W, Wyngaarden, J.B. (Des), $15^{\text {th }}$ Ed. W.B. Saunders, Philadelphia, 998-999.

Emerson, B.T. (1079). Toxic nephropathy. In: Cecil Textbook of Medicine, Beeson, P.B.; Mc Dermott, W; Wyngaarden, J.B. (eds) $15^{\text {th }}$ Ed. W.B. Saunders, Philadelphia p 1422-1434.

Ervin, M.E. (1983) Petroleum distillates and turpentine In: Clinical Management of Poisoning and Drug Overdose, Haddad, L.M. and Winchester, J.F (Des), W.B.V. Saunders, Philadelphia p 771-779.

Frankenberger, W.T. and Johnson, J.B. (1982) Influence of Crude Oil and refined petroleum products on Soil dehydrogenate activity. J. Environ. Quality. 11(4): 602-607.

International Programmer on Chemical Safety (IPCS) 1982). Environmental Health Criteria Series \#20, Selected Petroleum Products: Executive Summary, WHO, Geneva, p 1-7.

Jeffries, G.H. (1979) Toxic and Drug-induced liver disease In: Cecil Textbook of Medicine Beeson, P.B.; McDermott, W.; Wyngaarden, J.B. (Des) $15^{\text {th }} \mathrm{Ed}$, W.S. Saunders, Philadelphia, p 1657-1659.

Kiihnhold, W.W. (1980) Some aspects of the impact of aquatic oil pollution on fishery resources. FAO/UNDP South China Sea Fisheries Development \& Co-ordination Programmer, Manila, p 1-26.

Seight, J.G. (1992). Diesel fuels In: McGraw Hill Encyclopedia of Science and Technology, $7^{\text {th }} \mathrm{Ed}$. McGraw Hill Inc. New York, 5:207. 